\title{
PANDANGAN AGAMA KRISTEN TERHADAP PIDANA MATI
}

\author{
Netty SR Nairborhu \\ Dosen Tetap Sekolah Tinggi Hukum Bandung \\ E-mail:jurnal@sthb.ac.id
}

\begin{abstract}
According to Christian Religion point of view, punishment or penalty is not a retaliatory action, although it is required to equalize and balance the circumstance caused by a crime. Then, Christian Religion teaches that a man can forgive someone bacause God has forgiven him. Refering to death penalty, there are two points of views, namely supporting and refusing the application of death penalty. The main reason for those who support or accept it, is the criminal who has committed a crime must be punished, to a death penalty. Death penalty is a retaliatory action. Someone is God's servant and serving God's punishment to those who have committed crimes, more over God gives a power to the State to punish the criminals. To achieve the goal, everything has been arranged and poured in the form of the laws based on believed religion point of view. On the other hand, for those who resuse the application of the death penalty is that, death penalty is not effective in handling a crime as a long life imprisonment is much more precise and accurate than death penalty.
\end{abstract}

\section{Keywords: Religion Point of View; Death Penalty; Covenant.}

\begin{abstract}
Abstrak
Pandangan agama Kristen, hukuman bukanlah suatu balasan, walaupun hukuman diperlukan untuk menyeimbangkan keadaan akibat dari kejahatan tersebut. Selanjutnya dalam agama Kristen juga diajarkan bahwa orang dapat mengampuni karena Allah telah mengampuninya. Terkait dengan hukuman pidana mati terdapat dua pandangan yakni yang mendukung dan yang menolak diterapkannya hukuman pidana mati. Bagi yang mendukung (menerima) diterapkannya hukuman pidana mati dasarnya adalah penjahat yang telah melakukan kejahatan pantas dihukum, bahkan dengan hukuman mati. Hukuman mati merupakan pembalasan. Seseorang merupakan abdi Allah dan menjalankan hukuman Allah kepada mereka yang melakukan kejahatan, terlebih lagi Allah memberi kuasa kepada negara untuk menghukum bagi siapa saja yang berbuat kejahatan. Dalam perwujudan akan hal tersebut dituangkan dalam bentuk undang-undang dengan pandangan agama yang diyakini. Di sisi lain, bagi yang menolak (tidak setuju) diterapkannya pidana mati beralasan bahwa hukuman mati tidaklah efektif dalam menangani kejahatan sebab hukuman seumur hidup lebih tepat digunakan daripada hukuman mati.
\end{abstract}

Kata Kunci: Pandangan Agama, Pidana Mati, Perjanjian. 


\section{A. PENDAHULUAN}

Surat kabar, televisi, dan radio membanjiri kita dengan laporan-laporan kejahatan seperti perkosaan, perampokan bersenjata, pembunuhan, korupsi, dan lain-lain sehingga penyebaran ini mempengaruhi banyak orang. Beberapa kejahatan tersebut begitu mengerikan sehinggabanyakorangmenuntunhukuman mati dan banyak pula masyarakat kuno dan modern memperaktekan hukuman mati tersebut. Menurut mereka hukuman mati merupakan cara yang tepat untuk menghadapi penjahat-penjahat yang kejam. Apakah demikian yang paling tepat dan ampuh sehingga jera pelaku. Namun pendapat yang mendukung penerapan hukuman pidana mati, ditentang oleh pihak lain yang tidak setuju dengan penerapan pidana mati dan semakin banyak pula orang yakin bahwa hukuman mati merupakan kejahatan dan tidak pernah boleh digunakan. Di sini kita melihat argumen-argumen kedua belah pihak. Masalah-masalah yang diajukan memang sulit ditengahi. Sangatlah penting untuk memikirkan dengan hati-hati dan mempertimbangkan bukti sebelum mengambil kesimpulan. Membuat keputusan sebelum kita mulai kiranya tidak membantu kita untuk menemukan kebenaran.

Satu kejahatan dilakukan bila hukum yang dibuat oleh negara dilanggar. Sebenarnya hukum diciptakan untuk kebailam umum melindungi masyarakat. ${ }^{1}$ Oleh karena itu negara juga menentukan hukuman bagi para pelaku kejahatan dan pelanggaran hukum. Penentuan tentang apakah pidana mati dibenarkan di suatu negara seperti di Indonesia yang berlandaskan Pancasila, tentu juga harus memperhatikan pro dan kontra di antara aspek-aspek yang mempengaruhi pembentukan hukum tersebut, seperti pandangan para pemuka agama, faktor keadilan, dan lain-lain. Oleh karena itulah Persekutuan Mahasiswa Agama Kristen mencoba mengambil topik diskusi dalam programnya dengan judul "Pandangan Agama Kristen, Islam, dan Hukum Positif Terhadap Hukuman Pidana Mati." Pada kesempatan ini, penulis dipercayakan dengan judul "Pandangan Agama Kristen Terhadap Pidana Mati."

\section{B. PEMBAHASAN}

\section{Hukuman Sebagai Akibat Kejahatan dan Pelanggaran}

Kejahatan dapat diartikan suatu kegiatan yang merugiikan kebaikan umum yang dilarang oleh hukum (Kriminal) yang biasanya diteruskan dengan tuntutan dan bila terbukti dikenakan hukuman.

Di Inggris, hukuman merupakan akibat pelanggaran terhadap hukum dan pelaku dapat dikenakan ganjaran seperti: ${ }^{2}$ a. Ditahan (orang yang berumur diatas 21 tahun dikirim ke penjara dan kadangkadang hukuman ditangguhkan, pelanggra tidak langsung masuk penjara kecuali ia mengulangi lagi selama masa yang ditentukan. Dibawah usian 21 tahun dikirim ke Lembaga Pemasyarakatan usia muda).

\footnotetext{
Bandingkan tugas hukum oleh Roscoe Pound untuk mencapai Ketertiban dan Kepastian Hukum.

Simon Christoper Danes, Masalah-Masalah Moral Sosial Aktual Dalam Perspektif Iman Kristen, Penerbit Kasinius, Yogyakarta, 2000, hlm. 77.
} 
b. Didenda.

c. Diperintahkan untuk mengabdi kepada masyarakat dengan jumlah jam tertentu.

d. Dilepaskan dengan syarat pelanggran membuat penyataan tidak akan melanggar lagi.

e. Diperintahkan wajib lapor yang dibimbing oleh polisi. Para pelanggar usia muda pergi ke kantor polisi selama beberapa jam dan diberikan ceramah dan latihan fisik.

Alternatif-alternatif hukumannya pun dapat berupa:

a. Perintah masa percobaan, dimana pelangar harus wajib lapor kepada petugas masa percobaan atau hadir di pusat masa percobaan serta perintah masa percobaan ini dapat digabung dengan perintah pelayanan masyarakat.

b. Perawatan, artinya beberapa penjahat yang masih umur 18 tahun ke bawah dapat dimasukan dlam perawatan oleh pengusaha lokal.

c. Peringatan, beberapa pelanggar khususnya remaja diberikan peringatan resmi dari polisi.

Beberapa alternatif hukuman mencangkup masa percobaan, peringatan, pidana penjara dan pidana mati. Beberapa negara berbeda dalam menjatuhkan hukuman bergantung filosofi dan politik hukumannya yang dituangkan dalam hukum postitif (perundang-undangan).

Negara inggris tidak menjalankan hukuman mati, meskipun negara-negara lain menjalankannya. Penganiayaan, hukuman fisik, dan pemoyongan fisik dianggap ilegal walaupun menyetujui hukuman bagi para penjahat. Tujuan hukumnya dapat pula berupa:

a. Ganti rugi dalam arti pelanggar pantas dihukum dan menderita dengan cara tertentu atas apa yang dilakukannya.

b. Hukuman berupa pembalasan.

c. Hukuman dengan maksud menyeimbangkan kejahatan yang dilakukannya.

Menurut hukum taurat Yahudi: "Bila seseorang melukai orang lain, apapun yang telah dilakukannya akan dilakukan kepadanya. Bila ia mematahkan tulang, satu dari tulangnya akan dipatahkan; bila ia membutakan satu mata, satu dari matanya akan dibutakan; bila ia memukul jatuh sebuah gigi, satu giginya akan dipukul jatuh. Cidera apapaun yang diakibatkannya pada orang lain akan dilakukannya sebagai gantinya." 3

Perintah itu aslinya dirancang untuk membatasi balas dendam. Korban dapat mengambil mata untuk satu mata tetapi tidak boleh lebih. Namun, Yesus sama sekali membuang kemungkinan balas dendam.

Selanjutnya dalam perjanjian baru, dikatakan oleh Yesus: "Kamu telah mendengar apa yang dikatakan, 'mata untuk mata, dan gigi untuk gigi'. Tetapi sekarang Aku berkata kepadamu: janganlah membalas orang yang berbuat jahat kepadamu. Bila seorang menampar pipi kananmu, berikan juga pipi kirimu."4 
Kata-kata Yesus dimaksudkan bahwa orang-orang kristen tidak boleh menerima ide hukuman sebagai balasan. Namun, mereka mungkin menerima dengan baik bahwa hukuman itu perlu untuk menyeimbangkan kerugian yang disebabkan oleh kejahatan yang dilakukannya. Seorang pembunuh berhutang suatu kepada keluarga korbanya, ia harus membayar dengan cara yang sama untuk mengganti kehilangan mereka. ${ }^{5}$

Apakah menurut anda para penjahat haurs dituntut lebih banyak membantu atau mengganti kerugian korbannya?

Menurut Hukum Inggris, para petugas hukuman percobaan adalah para pekerja sosial yang mempunyai spesialis uuntuk bekerja sama dengan pengadilan. Mereka menangani masalah-masalah kriminal dan domestik. Sally miller telah mendaji petugas hukuman percobaan selama tujuh tahun terakhir. Pelayanan hukuman percobaan ini Kristen yang disebut misonaris Polisi Pengadilan, pada awal abad ke-20. Mereka membawa para pelanggra hukum muda ke rumah dan masyarakat mereka, serta mencoba merehabilitasu mereka. Sistem peradilan pidana mereka, mengambil tanggung jawab untuk menghukum kejahatan dari tangan para korban. Namun akhir-akhir ini, banyak kritikan disampaikan ibu korban, dan pelanggaran-pealanggaran melawan pribadi-pelangran dengan kekerasan, pelanggaran seks, pembunuhan-dihukum dengan keras agar orang itu dipenjara terus sehingga tidak dapat melakukan kejahatan lagi. Pengadilan cenderung menangani kejahatan terhadap hak milik-pencurian, pemalsuan, pencopetan, pembongkaran pabrik-dengan keras. Hukum sekarang sedang berusaha untuk membuat hukuman sesuai dengan kejahatan (ganjaran). Namun kemudian pandangan itupun berubah dengan mengatakan bahwa anda tidak memperbaiki penjahat dengan memenjarakannya dan mengambil semua hak dan tanggung jawabnya. Itu tidak mendidik orang bagaimana bertindak kalau sudah kembali ke dalam masyarakat. Beberapa yang mungkin akan dihadapi adalah tidak punya rumah, tidak dapat memenuhi kebutuhan, penghasilan terlalu kecil sehingga mencuri, diusir dari rumah dan harus bertahan hidu. Di penjara, makanan dan tempat tinggal disediakan walau dengan peraturan yang ketat. Anda tidak perlu membuat keputusan tentang kapan bangun pagi, apalagi apa yang dimakan. Jadi, masuk penjara membantu dalam mengahadapi hidup. Kenyataannya, orang sering membuat pelanggaran lagi sesudahnya.

Penjara merupakan sebuah institusi dan orang dimasukan dalam institusi itu dengan sangat cepat. Mereka menjadi tergantung pada institusi bila anda merampas tanggungjawab dan menyediakan rutinitas yang terstruktur, maka orang itu akan dengan cepat akan kehilangan kemampuan untuk membuat keputusan.

Dalam penjara terdapat bermacammacam kondisi dan perlakuan. Di penjara Victoria kuno seperti Wormwood scrubs

$5 \quad$ Simon Christoper Danes, Masalah-Masalah Moral Sosial Aktual Dalam Perspektif Iman Kristen, Penerbit Kasinius, Yogyakarta, 2000, hlm. 77. 
dan Wandsworth sangat dipenuhi penghuni. Tidak ada fasilitas untuk mandi dan toilet, banyak ember yang harus diisi air. Anda harus antri makanan. Beberapa penjara menawarkan pekerjaan seperti memhelem kantong surat, membuat baju, membersihkan penjara. Para tahanan mungkin bekerja sampai tiga belas kam per minggu, dan dapat memperoleh imbalan seluruhnya tujuh pound. Dengan itu mereka membeli apa saja yang mereka butuhkan selain makanan, sampo, sabun, sikat gigi, rokok, perangko kartu ulang tahun dan mereka tidak disubsidi. Suatu hari yang khas di penjara adalah seperti ini. Anda dibangunkan pada pukul 6.00, mengeluarkan ember, makan pagi, kembali ke dalam sel anda, makan siang pada 11.30, dan kembali ke dalam sel. Mungkin anda memperoleh waktu untuk berolahraga atau bersosialisasi. Kemudian makan sore pukul 16.30, kembali kedalam sel, dan anda dikurung sepanjang malam. Banyak tahanan hanya tidur sewaktu mereka dikurung. Itulah cara yang baik untuk menghabiskan waktu. Umumnya ada perpustakaan penjara, sehingga mereka bisa membaca. Mereka melakukan yang anda kerjakan, bahkan mereka juga mengadakan sharing. Sel-selnya bermacam-macam ukurannya. Sel khas Victoria dibangun untuk satu orang, dengan ruang hanya tempat tidur dan sebuah kursi. Terlalu padat merupakan masalah besar, dan mereka bekerja dengan memotong hukuman dan membangun penjara lagi. Huru-hara pada tahun 1980-an membuktikan keadaan sudah sangat kritis. Anda sama sekali tidak dapat melakukan itu untuk manusia dan berharap mereka keluar sebagai warga yang taat hukum. Keadaan sudah semakin baik. Sekarang sudah jarang ada tiga orang dalam satu sel.

Permasalahannya bisa terjadi bila satu sel dihuni bersama bisa mengakibatkan mudah marah, kegelisahan yang mendalam, pelanggaran terhadap wilayah pribadi, serangan homoseksual tergantung dengan siapa anda tinggal. Penjarang mengembangkan sendiri hierarki mereka, ada status yang harus dimenangkan dan dapat hilang. Mingkin anda memperoleh status sebagai orang paling kuat disana, tetapi kadang karena pelanggaran anda dihukum seumur hidup. Ada pula yang sama sekali tidak dapat diterima oelh tahanan lain, seperti pelanggar seks atau pembunuh anak-anak. Mereka disebut tahanan hukum 4, dan dipisahkan demi untuk melindungi mereka sendiri. Masalahnya adalah bahwa hal itu dapat menyatukan para pelanggar seks bersama, sehingga dengan begiu pandangan mereka menjadi hukum moral. Mereka saling mendukung.

Dalam teori, penjara seharusnya bertindak sebagai alat pencegah. Dalam praktek, kejahatan semakin meninggkat. Pencegahan dapat berhasil bila kejahatan direncanakan (bila dipikirkan sebelum dilakukan). Namun, beberapa orang tidak pernah memikirkan masak. Beberapa penjara mendampingi kelompokkelompok atau konseling yang dipimpin oleh petugas masa percobaan dan seorang petugas penjara. Mungkin ada kelompok-kelompok yang tingkah lakunya agresif. Kelompok-kelompok pelanggar seks dari gerakan menuju rehabilitasi dengan menyediakan program-program latihan kerja, pendididkan, kesehatan, 
kursus-kursus yang memberikan sertifikat atau ijazah. Namun, jangan terlalu banyak kegiatan karena penjara bukan tempat untuk memperbaharui hidup secara menyeluruh. Para tahanan tidak dapat mengganti rugi para korban secara finansial karena mereka tidak mempunyai uang sama sekali. Itulah masalah sebenarnya dengan para tahanan. Kompensasi merupakan gagasan tabf vauj saya kira, membayar kembali kesalahan sangatlah berharga. Para petugas masa percobaan telah membuat beberapa upaya untuk jadi perantara antara pelanggar dan korban meskipun tidak berlaku untuk semua pelanggaran.

Dengan praktik pemidanaan tersebut, patut dipertanyakan kembali, apa yang harus dilakukan di balik jeruji dan penjatuhan hukuman tersebut. Penjahat bukanlah masalah keturunan. Jika dihitung, sebenarnya kita pun betapa seringnya lakukan pelanggaran hukum. Dengan beberapa akibat pelanggranan dan kejahatan tersebut, kini selayaknya memikirkan kembali, apa tujuan pemidanaan tersebut dan bagaimana penerapannya atau merehabilitasi. Jeremy Bentham (1748-1832) mengatakan bahwa hukuman seharusya tidak lebih keras daripada yang dibutuhkan untuk mencegah para penjahat. Seandainya cukup dengan pencegahan, tidak akan ada kejahatan lagi. Para penjahat tidak pernah mengira atau memikirkan akan ditangkap sewaktu meeka melakukan kejahatan.

Banyak perdebatan-perdebatan yang dilakukan tentang pemidanaan ini. Sebagian orang berpendapat, para penjahat yang bahaya dapat melanggar kembali sehingga harus dijatuhkan dari orang lain dan masyarakat dan lebih aman. Sebagian berpendapat reformasi saja. Hukuman seharusnya memdidik para penjahat untuk mengubah perilaku menjadi baik. Bila seorang penjahat melanggar lagi, berarti hukumannya tidak berhasil. Sebagian lagi mengatakan rehabilitasi saja. Tetapi perlu diingat, ini bukanlah maksud hukuman tetapi sesuatu yang harus menyusul sesudahnya. Para pelanggar harus dibantu untuk kembali ke masyarakat setelah hukuman selesai. Mereka harus dibantu untuk mendapatkan pekerjaan dan memulai secara baru lagi. Pelanggar ini telah membayar kembali hutangnya kepada masyarakat.

Bagaimana pandangan iman kristen terhadap pelanggaran dan kejahatan? Alkitab mengatakan: "Ampunilah dosa-dosa kami, sebagaimana kami mengampuni orang yang telah berdosa kepada kami." Ini adalah doa dan ajaran Yesus kepada para pengikutnya, karena kepahitan tidak mampu mengampuni, tetapi merusak orang dari dalam. Pengampunan tidak berarti membiarkan orang menginjak-nginjak kita, walaupun pengampunan itu sangat sulit, namun sangat penting khususnya bagi korban kejahatan. Pengampunan tidak perlu sekaligus diberikan untuk segala kejahatan yang telah dilakukan, tapi harus ditinjau lagi. Orang Kristen percaya bahwa orang dapat mengampuni karena Allah telah mengampuninya, melalui kematian Yesus sehingga orang dapat kembali mempunyai hubungan yang benar dengan Allah, dipulihkan sampai tidak khawatir lagi dan yakin untuk tidak mengulangi lagi kejahatan (dosa). Mereka kembali dibebaskan, bebas untuk mencinta, bebas 
untuk mengampuni, bebas untuk menjadi manusia sejati.

Yesus mengajarkan bahwa orang harus siap dan bersedia mengampuni, tetapi pengampunannya harus di terima juga. (Misalnya, anda memberi saya hadiah, saya harus bersedia menerimanya.) Untuk menerima pengampunan saya harus mengakui telah berbuat salah. Dengan penyesalan dan igin mengumbah sikap saya. Hal ini benar-benar membutuhkan usaha berulang kali untuk memperbaiki kerusakan hubungan tersebut. Dalam Gereja Katolik orang yang pergi ke kamar pengakuaan harus siap untuk membuat silih sebelum ia dapat meminta imam menyatakan pengampunan Allah (abolisi). Orang Katolik dan banyak orang Kristen lain mengakui dosa-dosa mereka kepada imam, yang mereka yakini mempunyai kuasa mengampuni yang mengatakan kepada mereka bahwa dosa-dosa mereka telah diampuni, karena kuasa yang diberikan oleh Yesus Kristus.

Jadi, ada dua sisi pengampunan yaitu memberi dan menerima. Memberi artinya siap untuk mengampuni, dan menerima artinya menyesal dan siap membuat silih atau mengubah terus menerus sehingga dipulihkan (direhabilitasi). Sebagai perbandingan dapatlah direnungkan perumpamaan anak yang hilang dalam Lukas 15 : 11-32 yang menjelaskan bahwa anak tersebut bertingkah buruk tetapi ia menyesali dirinya. Sejak ia meninggalkan rumah, ayahnya selalu menanti dan ingin mengampuninya. Ayahnya begitu senang melihat anaknya bertobat sehingga ia berpesta besar. Seperti itulah pengampunan Allah cepat, murah hati, panjang saabar sehingga menyentuh hati yang terdalam anaknya. Tidak menggerutu seperti kakanya, selanjutnya Yesus pun mengampuni Pembunuhan dalam, Lukas 22 : 32-43 Ampunilah mereka sebab mereka tidak mengetahui, apa yang telah diperbuatnya demikian pula dalam doa Bapa Kami orang Kristen berdoa, ampunilah kesalahan kami seperti kamii juga mengampuni kesalahan orang yang berdosa pada kami, apabila hal ini kita bandingkan dengan hamba yang tidak mengampuni (Mat 18: 22-35) dan Pasal 5 dari United Nations Universal Declaration of Human Right yang mengatakan bahwa: "Tak seorang pun boleh disiksa atau diperlakukan atau dihukum secara kejam, tidak manusiawi dan merendahkan martabat manusia." Oleh karena itu marilah kita diskusikan, bagaimana ajaran Yesus mempengaruhi pandangan orang Kristen mengenai hukuman sebagai akibat kejahatan dan bagaimana seharusnya para penjahat dihukum, rekomendasikan.

\section{Hukuman Pidana Mati}

Terhadap hukuman pidana mati ini, terdapat dua pandangan yang mendukung dan menolak diterapkan hukuman pidana mati.

a. Pandangan yang mendukung (menerima)

Penjahat yang mengerikan pantas menerima hukuman mati. Hal ini berarti masyarakat tidak mentoleransi kejahatan seperti itu. Dalam kejadian 9:6 setelah air bah selesai Tuhan berfirman kepada Nuh, bahwa siapa yang merupakan darah manusia, darahnya akan tertumpah ileh manusia, sebab Allah membuat manusia itu menurut gambar-Nya 
sendiri. Jadi di sini hukuman mati merupakan pembalasan. Selanjutnya dalam surat Paulus kepada jemaat Roma, mengatakan bahwa seorang penguasa adalah abdi Allah dan menjalankan hukuman Allah kepada mereka yang melakukan kejahatan. Pemimpin reformasi Martin Luther setuju dengan Paulus yang mengatakan, Allah memberikan kuasa kepada negara untuk menghukum mereka yang bertindak salah. Dalam perwujudan penguasa atau pemerintah menuangkan hukuman itu dalam bentuk undang-undang yang dilandasi dengan pandangan agama yang diyakini.

b. Pandangan yang menolak (tidak setuju)

Bila pembunuhan itu salah, mengapa hukuman mati dibenarkan? Bila anda mengatakan bahwa para pemerkosa harus diperkosa, penyiksa disiksa, dan pembakar dibakar?

Menurut pandangan pertama, hukuman mati harus dijalankan supaya benar-benar adil dan berhasil. Namun pandangan ini ditentang oleh pandangan kedua denan mengatakan Bagaimanakah dalam kenyataanya? Beberapa terpidana, tahanan dapat pengampunan kadangkadang tidak. Apakah sudah adil dan berhasil serta sudah tidak ada masalah? Di Singapura, dapat dikenakan hukuman mati karena memiliki lebih dari 15 gr heroin. Bagaimanakah jika seseorang memiliki 14.99 gr, apakah dikenakan hukuman mati seperti yang memiliki herion 15 gr tersebut. Ternyata dengan diterapkan pidana mati belum tentu membawa keadilan dan selesai permasalahan.
Selanjutnya dikatakan bahwa tidak semua orang kristen menyetujui hukuman mati seperti dalam kisah air bah. Beberapa orang mengartikannya biarlah keadilan Allah akhirnya yang akan menimpa mereka yang berbuat jahat. Janganlah kita yang menghakiminya sebab tidak benar kita yang membunuh manusia yang diciptakan menurut gambar Allah. Hendaknya katakata Yesus jangan dikesampingkan dengan kata-kata mengampuni. Sebab dikatakan pula Matius 5:38-39, 43-44 mengatakan bahwa:"Kamu telah mendengar firman. 'mata ganti mata dan gigi ganti gigi'. Tetapi Aku berkata kepadamu: janganlah kamu melawan orang yang berbuat jahat kepadamu, melainkan siapa pun yang menampar pipi kananmu, 'kaisihilah sesamamu manusia dan bencilah musuhmu tetapi aku berkata kepadamu: Kasihilah musuhmu dan berdoalah bagi mereka yang menganiayamu."Yesus tidak pernah mengatakan sesuatu langsung mengenai hukuman mati. Kita tahu Yesus adalah teman kaum terbuang, yang dianggap sebagai penjahat. Ia menginginkan mereka untuk bertobat, mengubah pikiran dan jalan hidup mereka. Jadi akan sangat aneh bila Yesus setuju penjahat dikenakan pidana mati.

Sewaktu Paulus menulu surat ke roma, ia mencoba menunjukan bahwa orang kristen tidaklah berbahaya secara politik. Ia tidak mempersoalkan masalah apakah seorang penguasa memperoleh kekuasaanya dari Allah. Misalnya seperti Hitler yang melegalkan hukuman mati. Namun Desmond Tutu, Uskup Agung tidak setuju dan menentang hukuman mati. Begitu juga Coretta Scott King, janda Martin Luther King Paus Yohanes Paulus II 
berhasil lolos dari usaha pembunuhan atas dirinya pada tahun 1981. Ia mengampuni orang yang mencoba membunuhnya. Ia menyatakan bahwa kepuasannya menganugerahkan belas kasih, bahkan pengampunan bagi mereka yang dihukum mati. Walaupun pada waktu itu Katekismus Universal Gereja Katolik mendukung hak negara untuk menjatuhkan hukuman pidana mati.

Sebaliknya pendapat yang kedua mengatakan bahwa orang tidak akan melakukan kejahatan serius bila mereka tahu akan mati untuk itu. Hukuman mati akan mencegah para calon pembunuh dan teroris. Pendapat yang menolak hukuman mati mengatakan tidak cukup bukti bahwa hukuman mati merupakan alat pencegah yang efektif. Justru sebaliknya dalam laporan PBB tahun 1988 menunjukan bahwa hukuman mati tidak efektif lagi sebagai pencegah dibandingkan dengan hukuman seumur hidup. Hal ini dipertegas pula oleh Kejaksaan Agung Amerika Serikat, bahwa hukuman mati itu bukanlah alat pencegah. Biasanya sebagian besar penjahat membunuh sewaktu mereka sangat emosional, mabuk atau panik. Mereka tidak dapat berpikir dengan lurus. Pada tahun 1957-an suatu studi di jepang memperlihatkan bahwa dari 145 pembunuh ternyata tak seorang pun berpikir bahwa dia akan dikenakan hukuman mati.

Lagi pula apabila hukuman mati itu berhasil mencegah orang lain untuk tifak melakukan kejahatan tentunya kejahatan akan semakin berkurang, ternyata tidak. Seandainya berhasil, kejahatan seperti itu akan meningkat tajam sewaktu hukuman mati dihapus, ternyata tidak. Di Kanada, tingkat pembunuhan sebenarnya turun sejak hukuman mati dihapuskan pada tahun 1976. Juga tidak ada bukti bahwa pengedar obat terlaramg dicegah dengan hukuman mati. ${ }^{6}$ Para teroris umumnya siap mati untuk tugas mereka. Menghukum mati mereka berarti menjadikan mereka martir. Itu malah mendorong makin keras dari kelompok teroris untuk membalas dendam.

Singkatnya, menurut pendapat yang pertama atau mendukung mengatakan bahwa hukuman mati akan menghentikan para penjahat melakukan kembali sehingga masyarakat terlindungi.

Berbeda halnya pendapat yang kedua yang mengatakan bahwa lebih baik diterapkan hukuman seumur hidup saja. Sebab, tidak ada jaminan bahwa seseorang akan melanggar hukum lagi apabila yang diterapkan adalah hukuman mati dan bukti menunjukan bahwa para pembunuh jarang melakukan lagi kejahatan-kejahatan yang sama. Demikianlah pendapat yang pro dan kontra terhadap hukuman pidana mati.

Dalam perkembangan berikutnya paham demokrasi mengatakan bahwa sebagian besar rakyat di banyak negara lebih senang hukuman mati dan bila tidak digunakan, pemerintah akan menolak keinginan rakyatnya. Namun sebaliknya pendapat yang menolak menganggap hal itu tidak benar. Orang Kristen yakin moralitas yang datang dari Allah bukanlah sekedar perbedaan pendapat. Bila pendapat umum mendukung penyiksaan, 
penyiksaan tetaplah salah. Mungkin saja sebagian besar rakyat yang menginginkan hukuman mati tidak benar-benar mengerti atau memahami dasar-dasarnya tetapi karena itu pendapat orang banyak itulah yang dianggap benar walaupun ternyata tidak efektif.

Dari sudut pandang ekonomi ada pula yang mendukung dan menolak. Pihak yang mendukung mengatakan bahwa hukuman mati lebih murah dari pada memenjarakan seumur hidup, sedangkan yang menolak mengatakan bahwa biaya lebih murah membiarkan pasien di rumah sakit dari pada meneruskan perawatan. Hukuman mati terlalu penting untuk diputuskan atas alasan ekonomi. Kenyataanya, pengadilan hukuman mati di Amerika Serikat lebih mahal dari pada pemenjaraan seumur hidup. Harga proses hukum sangatlah tinggi. Jelas pendapat tersebut menginformasikan kepada kita adanya pihak yang mendukung dan menolak.

Amnesti Internasional organisasi dunia pun mengkampanyekan dengan menolak penyiksaan dan hukuman mati kecuali untuk kejahatan tertentu. Selain itu penerapan hukuman pidana mati kadangkadang disalahgunakan oleh pemerintah yang bobrok terhadap lawan politiknya, terutama setelah kup. Hukuman mati cenderung digunakan untuk mereka yang orang miskin dan mereka yang tidak beruntung damal masyarakat karena tidak mampu membayar ahli hukum. Sebagai contoh Afrika Selatan, orang kulit hitam lebih mungkin digantung dari pada kulit putih. $^{7}$ Antara juni 1982 sampai Juni 1983, dari 154 orang Afrika Selatan yang dianggap bersalah atas pembunuhan : 81 orang kulit hitam yang membunuh kulit putih-38 digantung, 52 orang kulit putih membunuh kulit putih - 1 digantung, dan 21 orang kulit putih membunuh kulit hitam - tak seorangpun digantung.

Apabila hasil penelitian tersebut dihubungkan dengan ajaran Alkitab maka dapat dikeahui bahwa hukuman mati itu terlalu final dan tidak adil. Yesus sendiri dihukum mati secara tidak adil. Suatu studi yang dilakukan pada tahun 1987 di Amerika Serikat menunjukan bahwa 350 orang dinyatakan bersalah atas kejahatan besar sekarang ini nyatanya tidak bersalah. (23 diantaranya dihukum mati. Kini dinyatakan bersalah atas kejahatan besar padahal tidak bersalah ternyata 23 diantaranya menjalani hukuman mati. Selain itu mereka mengatakan bahwa pelaksanaan hukuman mati bersifat brutal dan berdarah dingin, mengarah kesadisme. Bahkan bila hukuman mati diterapkan orang Kristen percaya tak bertobat (mengubah perilaku) menjadi pulih dengan Allah adalah hak yang diberikan Allah. Pemerintah tidak dapat mengambil hak itu melalui Undang-Undang dengan alasan tingkah lakunya buruk, betapapun mengerikannya kejahatan itu. Akan tetapi jangan disalah artikan bahwa penjahat tidak akan dihukum tetapi, diberikan ganjaran berupa hukuman lain diluar hukuman mati seperti hukuman seumur hidup.

Dalam perkembangan terakhir ini PBB telah mengambil sikap mendukung penghapusan hukuman mati (Amnesti Internasional) dengan mengatakan 
tak seorang pun boleh disiksa atau diperlakukan atau dihukum secara kejam, tidak manusiawi atau merendahkan martabat manusia. ${ }^{8}$ Dewan Gereja Dunia pun lebih suka abolisi walau beberapa orang Kristen tidak setuju.

Dari beberapa uraian di atas, menginformasikan kepada kita bahwa pandangan Kristen dalam ajaran Yesus pada Alkitab terutama perjanjian baru menolak hukuman pidana mati.

\section{PENUTUP}

Berdasarkan uraian-uraian sebelumnya dapatlah diketahui bahwa: Kitab Taurat dalam Perjanjian Lama menetapkan adanya hukuman mati utu kejahatankejahatan tertentu seperti seorang saksi yang membuat tuduhan palsu, perzinahan, dan lain-lain (Ulangan 19:15-21) Mata ganti mata, gigi ganti gigi.

Berbeda halnya dalam pernajian baru, tidak mengenal hukuman mati kecuali mereka.YesusmenggenapiPerjanjianLama dan Taurat dan kita hidup sekarang dalam hukuman yang baru yaitu pengampunan dan kasih yang sejati yang merehabilitasi dan memulihkan persekutuan kita dengan Allah karena manusia diciptakan segambar dan serupa dengan Allah. Yohanes 7:23-24 dan Yohanes 8:11 menjelaskan kepada kita bahwa sekalipun menurut Taurat, Farisi, dan ahli Taurat mengatakan bahwa perbuatan-perbuatan tertentu seperti zinah dan saksi palsu harus dihukum mati, tapi Yesus menjawab pertanyaan perangkap pada waktu itu dengan mengatakan: barangsiapa yang tidak berdosa, hendaklah ia yang pertama menghukum pezinah tersebut. Dan tak seorang pun yang berani lalu Yesus mengatakan, Aku pun tak menghukum engkau, pergilah jangan berbuat dosa lagi mulai dari sekarang. Dari ayat-ayat tersebut dapat diketahui bahwa hukuman mati tidak dibenarkan menurut iman Kristen.

Walaupun mati tidak dibenarkan menurut iman kristen, bentuk-bentuk hukuman lainnya dapat dikenakan sesuai dengan hukum positif di masingmasing negara seperti Indonesia denga berlandaskan Pancasila sebagai sumber dari segala hukum di Indonesia. Demikian juga di negara-negara Ingris, Amerika Serikat, dan negara lainnya yang telah menghapuskan hukuman pidana mati pada umumnya bersumber pada ajaran Kristiani yang mengutamakan pengampunan dan mengasihi sesama.

\section{DAFTAR PUSTAKA}

Alkitab, Lembaga Alkitab, Jakarta 2006.

Alkitab, Edisi Studi, Lembaga Alkitab Indonesia, 2011.

Doroty I Marx, Bolehkah Aku Percaya, Yayasan Kalam Hidup, Bandung, Tanpa Tahun.

Doroty I Marx, Pandangan Agama Kristen Tentang New Morality (Bahan Kuliah Pendidikan Agama).

J. Gede A.B Wiranata, S.H., M.H., Pasar Etika dan Moralitas (Pengantar Kajian Etika

$8 \quad$ Pasal 5 Deklarasi HAM PBB. 
Profesi hukum), PT. Citra Aditya Bakti, Bandung 2005.

Simon dan Christoper Danes, MasalahMasalah Moral Sosial Aktual dalam Perspektif Iman Kristen, Kanisius, Yogyakarta, 2000. 